\title{
PENGARUH LINGKUNGAN NON FISIK PESANTREN DAN KECERDASAN EMOSIONAL TERHADAP PENYESUAIAN REMAJA (KASUS PESANTREN MODERN)
}

\author{
Indah Rizki Annisa $^{\left.1^{*}\right)}$, Alfiasari ${ }^{1}$ \\ ${ }^{1}$ Departemen IImu Keluarga dan Konsumen, Fakultas Ekologi Manusia Institut Pertanian Bogor, \\ Bogor 16680, Indonesia \\ *)E-mail: annisarizkiindah@gmail.com
}

\begin{abstract}
Abstrak
Kemampuan untuk beradaptasi baik terhadap diri sendiri maupun dengan lingkungan secara harmonis menjadikan penyesuaian sebagai proses yang penting bagi setiap individu. Keluarga dan sekolah atau dalam hal ini pondok pesantren modern/ sekolah berasrama sebagai bagian dari mikrosistem mempunyai dampak langsung pada penyesuaian remaja. Penelitian ini bertujuan menganalisis pengaruh lingkungan non fisik pesantren dan kecerdasan emosional terhadap penyesuaian remaja. Populasi penelitian ini adalah siswa kelas delapan Sekolah Menengah Pertama Islam Terpadu (SMPIT) berasrama di Kabupaten Subang, dengan contoh yang dipilih dengan teknik stratified random sampling sebanyak 100 siswa. Hasil penelitian menunjukkan kualitas lingkungan non fisik sekolah, kecerdasan emosional, dan penyesuaian remaja berada pada kategori cukup baik. Besar keluarga berhubungan negatif signifikan dengan penyesuaian remaja. Selain itu, pendapatan keluarga memiliki hubungan positif dengan meningkatnya penyesuaian remaja. Hasil uji regresi menunjukkan bahwa lingkungan non fisik pesantren dan kecerdasan emosional berpengaruh positif terhadap penyesuaian remaja. Temuan ini menegaskan pentingnya lingkungan pesantren yang kondusif untuk dapat meningkatkan kemampuan penyesuaian para siswanya.
\end{abstract}

Kata kunci: kecerdasan emosional, lingkungan pesantren modern, penyesuaian, remaja

\section{The Influence of Non Physical Environment of Islamic Boarding School and Emotional Intelligence on Adolescent's Adjustment (Case of Modern Islamic Boarding School)}

\begin{abstract}
The adaptation ability of children both to the self and to the environment harmonically is important process for every child. Families and schools which are, in this case, is the Islamic boarding school are part of microsystem that has a direct influence on adolescent's adjustment. This study aimed to analyze the influence of non-physical environment of Islamic boarding school and emotional intelligence on adolescent's adjustment. The population of this study was the eighth-grade students of Integrated Islamic Junior High School (SMPIT) in Kabupaten Subang. The participants were selected by stratified random sampling and involved 100 students as participants. The results showed the quality of the non-physical environment of Islamic boarding school, emotional intelligence, and adolescent's adjustment was in the medium category. Family size is negatively correlated with the emotional intelligence of the adolescents. In addition, the family income is positively correlated with increasing of adjustment. Results of regression analysis showed that non-physical environment of Islamic boarding school and emotional intelligence give a positive influence on adolescent's adjustment. These findings revealed the importance of conducive environment of Islamic boarding school to increase the ability of the pupil's adjustment.
\end{abstract}

Keywords: adjustment, adolescent, emotional intelligence, Islamic boarding school, non physical environment

\section{PENDAHULUAN}

Masa remaja adalah masa tansisi yang membawa seorang individu untuk meninggalkan tahap kanak-kanak menuju tahap kedewasaan. Masa remaja merupakan periode transisi yang ditandai dengan perubahan individu dalam segala aspek baik fisik, sosial, psikologi, dan mental. Pada periode ini, kebutuhan remaja untuk mengekspresikan diri dan bersosialisasi dengan teman-teman sebayanya berkembang pesat. Remaja merasa dirinya sudah mandiri, memiliki rasa ingin tahu yang besar, selalu ingin mencoba banyak hal baru yang belum diketahuinya, serta tidak ingin ketinggalan dari teman-temannya. Masa remaja memberikan kesempatan untuk tumbuh, tidak hanya dalam 
dimensi fisik, tetapi juga kompetensi kognitif dan sosial, otonomi, harga diri, dan keintiman. Periode ini disebut masa kritis, karena sebagian remaja mengalami gejolak emosional, konflik dalam keluarga, perilaku gegabah, dan menolak nilai-nilai orang dewasa (Santrock, 2007). Perubahan di masa remaja banyak terlihat mulai dari perubahan fisik terkait masa pubertas sampai dengan perubahan psikologis yang menghadapkan remaja pada tugas-tugas kedewasaan (Erikson, 1963). Sejalan dengan teori Bronfenbrenner (1985), faktor lingkungan serta orang-orang yang berada disekitarnya sangat kuat memengaruhi perkembangan anak. Sikap dalam proses penyesuaian diri merupakan bentuk penyelarasan antara kondisi yang terjadi dalam diri sendiri dan lingkungan sekitar. Paradigma bioekologis Bronfenbrenner (1979) menjelaskan bahwa setiap mikrosistem seperti keluarga dan sekolah dapat saling berinteraksi dalam mesosistem yang akhirnya berpengaruh pada perkembangan individu.

Data Analisis Statistik Pendidikan Islam Kementerian Agama Republik Indonesia, menunjukkan bahwa pada Tahun 2011-2012 terdapat 27.230 pondok pesantren yang tersebar di seluruh Indonesia. Populasi Pondok Pesantren terbesar berada di Provinsi Jawa Barat, Jawa Timur, Jawa Tengah dan Banten yang berjumlah 78,60 persen dari jumlah seluruh Pondok Pesantren di Indonesia, dengan rincian Jawa Barat 7.624 (28,00\%), Jawa Timur 6.003 (22,05\%), Jawa Tengah $4.276(15,70 \%)$, dan Banten 3.500 (12,85\%). Hartono (2006) menjelaskan bahwa pondok pesantren merupakan bagian dari sistem pendidikan nasional yang memiliki fokus tidak hanya pada ilmu pengetahuan umum tetapi juga ilmu agama. Pada kondisi ini remaja dituntut memiliki kemampuan penyesuaian diri yang baik dengan latar belakang sosial yang berbeda, baik daerah asal, bahasa, ekonomi, serta tingkatan umur untuk mampu menyesuaikan diri terhadap segala aktivitas, budaya, dan kebiasaan yang ada di lingkungan pesantren. Menurut Efendi (2013) dengan segala pembelajaran di pesantren diharapkan remaja mampu berperan dalam menangani masalah-masalah sosial di lingkunganya. Oleh karena itu, pesantren sebagai salah satu lembaga pendidikan Islam dituntut untuk mampu ikut berkompetisi dalam upaya menciptakan suatu inovasi kreatif terhadap sistem ataupun metode pembelajaran yang telah ada.

Setyowati, Hartati, dan Sawitri (2010) menyatakan individu yang mempunyai kecerdasan emosional yang tinggi akan mampu mengatasi berbagai masalah atau tantangan yang muncul dalam hidupnya. Emosi remaja seringkali meluap-luap (tinggi), dan emosi negatif lebih mudah muncul. Menurut Goleman (2005) ada tiga jenis emosi negatif yang sangat menguasai remaja yang diwujudkan dalam bentuk ekspresi wajah yaitu emosi sedih, marah, dan takut. Kecerdasan emosional telah menjadi salah satu pengukuran yang tepat dilakukan pada remaja, karena peran emosi sangat penting dalam organisasi perilaku manusia seperti keterlibatan diri pada lingkungan, pengambilan keputusan, kolaborasi dan kerjasama, serta pengaturan stres (Morrison, 2007). Tanpa kemampuan pengelolaan emosi yang baik, individu akan mengalami kesulitan dalam bergaul dengan orang lain. Kecerdasan emosi tidak seketika terbentuk tanpa adanya sebuah proses latihan dan pembelajaran. Ketika seseorang mampu mengontrol emosi yang dimiliki, mengenali emosi, mampu memotivasi diri, mampu berempati dengan orang lain, serta mampu membina hubungan yang efektif dengan orang lain dengan baik semakin tinggi pula kecerdasan emosinya. Pesantren sebagai lingkungan tempat tinggal remaja juga memengaruhi tingkat kecerdasan emosi. Tentu saja hal itu sangat terkait dengan upaya peningkatan kulitas sumber daya manusia bangsa ini yang ada pada generasi muda pada diri remaja. Penelitian yang dilakukan Dwiperdanasari (2010) menunjukkan bahwa kecerdasan emosi pada remaja yang tinggal di pondok pesantren lebih tinggi dari pada kecerdasan emosi yang dimiliki remaja yang tidak tinggal di pondok pesantren. Hal tersebut menunjukkan lingkungan sekolah memengaruhi tinggi rendahnya tingkat kecerdasan emosi pada diri remaja.

Beberapa penelitian mengenai kecerdasan emosional berkaitan dengan banyak aspek kehidupan dan proses penyesuaian dalam kehidupan sehari-hari. Seperti halnya pada penelitian Ladd et al. (2008) menunjukkan bahwa kecerdasan emosi remaja laki-laki dan perempuan yang dilihat dari proses interaksi dengan teman kelas dan stabilitas hubungan pertemanan pada remaja sekolah menengah memengaruhi perkembangan dan penyesuaian diri remaja. Pada penelitian yang dilakukan Kidger et al. (2011) menunjukkan bahwa lingkungan sekolah memiliki pengaruh besar pada kecerdasan emosional remaja, sehingga sekolah perlu membangun intervensi yang efektif dan layak pada keseluruhan program sekolah yang kompleks. Hal ini memiliki makna bahwa sekolah atau dalam hal 
ini pesantren modern yang memiliki lingkungan non fisik yang baik akan menghasilkan siswa remaja yang mempunyai kecerdasan emosional yang baik pula. Wang (2009) dengan partisipan remaja dari 23 sekolah menengah memperlihatkan adanya hubungan lingkungan non fisik sekolah yang dikhususkan melihat kompetensi dan dukungan emosional guru yang semakin baik mampu meningkatkan kemampuan penyesuaian diri remaja dan semakin rendahnya perilaku menyimpang remaja dan depresi.

Individu yang mulai memasuki masa remaja akan menghadapi masa yang penuh konflik sehingga menimbulkan keresahan dan kontradiksi pada diri remaja. Data Survei Demografi dan Kesehatan Indonesia 2012 tentang Kesehatan Reproduksi Remaja dari BPS, BKKBN, dan Kementrian Kesehatan RI (2012) melaporkan bahwa persentase remaja usia 15-19 tahun Indonesia sebanyak merokok $(74,4 \%)$, minum minuman beralkohol $(30,2 \%)$, menggunakan narkoba $(2,8 \%)$ dari total 6.835 remaja laki-laki. Sementara itu, pada remaja wanitanya terdata sebanyak merokok $(8,9 \%)$, minum minuman beralkohol (3,5\%), dan menggunakan narkoba $(0,1 \%)$ dari total 6.018 orang. Berbagai perilaku menyimpang dari permasalahan remaja tersebut menunjukkan kegagalan penyesuaian diri pada remaja yang berelevansi pada rendahnya tingkat kecerdasan emosi di kalangan remaja. Kecerdasan emosional dan penyesuaian diri merupakan bagian dari tugas-tugas perkembangan remaja yang dirasa penting untuk selalu diperhatikan. Hasil penelitian Handono dan Bashori (2013) menunjukkan bahwa permasalahan yang sering dirasakan oleh para santri di pesantren adalah hambatan penyesuaian diri, kesulitan bergaul, sulit berkomunikasi dengan teman, maupun dengan lingkungan tempat tinggal sehingga menimbulkan stres dan berpengaruh pada tugas dan tanggung jawab sebagai seorang santri. Santri yang belajar di pondok pesantren pada dasarnya tidak hanya berasal dari daerah dimana pondok pesantren tersebut berdiri, tetapi juga berasal dari luar kota, luar provinsi bahkan ada yang berasal dari negara berbeda. Maka setiap santri yang berasal dari berbagai wilayah yang berbeda tersebut secara otomatis akan menempati tempat tinggal baru di dalam pondok pesantren yang tentunya akan berbeda dengan tempat tinggal sebelumnya serta bersama-sama dengan para santri lainnya yang berbeda latar belakang budaya dan tempat tinggal. Lingkungan non fisik pesantren tidak selalu dapat dijalani dengan baik oleh santri, faktanya banyak dari santri tersebut mengalami kendala dalam berbagai hal. Menghadapi tantangan seperti ini para santri selayaknya bisa menyesuaikan diri dengan baik dimana penyesuaian diri merupakan salah satu persyaratan penting bagi terciptanya kesehatan jiwa atau mental individu.

Menurut Kumalasari dan Ahyani (2012) mengungkapkan bahwa kegagalan remaja dalam melakukan penyesuaian diri akan menimbulkan bahaya seperti tidak bertanggung jawab dan mengabaikan pelajaran, sikap sangat agresif dan sangat yakin pada diri sendiri, perasaan tidak aman, merasa ingin pulang jika berada jauh dari lingkungan yang tidak dikenal, dan perasaan menyerah. Berdasarkan pemaparan tersebut penelitian ini bertujuan untuk: 1) mengidentifikasi karakteristik lingkungan non fisik pesantren, kecerdasan emosional dan penyesuaian remaja yang tinggal di pesantren berdasarkan jenis kelamin; 2) menganalisis karakteristik remaja, karakteristik keluarga, lingkungan non fisik pesantren, dan tingkat kecerdasan emosional terhadap penyesuaian remaja yang tinggal di pesantren.

\section{METODE}

Penelitian ini menggunakan desain penelitian cross sectional. Lokasi penelitian adalah Sekolah Menengah Pertama Islam Terpadu (SMPIT) As-Syifa Boarding School Kabupaten Subang. Pemilihan tempat dilakukan secara sengaja (purposive) dengan pertimbangan lokasi penelitian adalah salah satu lembaga pendidikan Islam modern yang unggul menggunakan metode dan pendekatan pembelajaran terbaik yang memiliki siswa yang berasal dari daerah dengan latar belakang keluarga dan budaya yang beraneka ragam. Pengambilan data dilaksanakan pada bulan Maret 2016.

Populasi penelitian berjumlah 800 siswa. Namun, mengingat penelitian ini menilai proses penyesuaian sosial maka untuk mengurangi bias antarpartisipan maka ditetapkan kerangka contoh berjumlah 268 siswa (134 laki-laki dan 134 perempuan), yakni siswa kelas delapan SMPIT As-Syifa Boarding School kerangka contoh ini dipilih karena minimal telah 1 tahun tinggal di pesantren sehingga dirasa cukup memiliki pengetahuan dan pengalaman tentang kehidupan di pesantren. Berdasarkan Rumus Slovin untuk menentukan besar contoh dengan error 10,0 persen maka penelitian minimum melibatkan 73 siswa sebagai partisipan. Teknik 
pengambilan contoh dalam penelitian ini adalah dengan menggunakan teknik stratified random sampling dan ditetapkan jumlah contoh sebanyak 100 siswa yang dibedakan 50 siswa putri dan 50 siswa putra sebagai subjek pelaksanaan penelitian.

Jenis data yang dikumpulkan dalam penelitian ini adalah data primer. Data primer diperoleh melalui pengisian kuesioner (self-administred) oleh para siswa responden yang kemudian diujikan reliabilitas dan validitas instrumennya. Data primer yang dikumpulkan meliputi karakteristik remaja, karakteristik keluarga, preferensi siswa terhadap lingkungan non fisik sekolah, kecerdasan emosional responden dan penyesuaian remaja. Variabel karakteristik remaja meliputi usia remaja, jenis kelamin, dan urutan kelahiran. Variabel karakteristik keluarga mencakup usia orang tua, pendidikan orang tua, pekerjaan orang tua, pendapatan keluarga dan besar keluarga. Variabel kecerdasan emosional memuat kesadaran diri, pengaturan diri, motivasi, empati, dan keterampilan sosial. Selanjutnya, variabel lingkungan non fisik pesantren terdiri atas sebagai berikut: 1) metode, pendekatan guru dan wali asrama, dan kompetensi siswa; 2) aktivitas belajar dan mengajar; 3) komunikasi dan partisipasi orang tua dengan sekolah; 4) interaksi guru dan wali asrama kepada siswa; dan 5) peraturan dan sanksi yang berlaku di pesantren. Pada variabel terikat, subvariabel dalam variabel penyesuaian diri remaja meliputi hubungan pertemanan, kebiasaan, kesehatan emosional, dan penarikan diri.

Data dari instrumen sebelum diolah dilakukan uji reliabilitas dan validitas untuk menunjukkan instrumen dapat diandalkan. Instrumen lingkungan non fisik pesantren mengembangkan dari penelitian Utami (2014). Jumlah pernyataan intrumen penelitian untuk variabel preferensi siswa terhadap lingkungan non fisik pesantren terdapat sejumlah 68 butir pernyataan. Pernyataan mengenai metode, pendekatan guru dan wali asrama, dan kompetensi siswa berjumlah 24 pernyataan yang dimodifikasi menjadi 22 pernyataan yakni menggabungkan pernyataan pembahasan dan penjelasan yang guru berikan kepada saya dikaitkan dengan kondisi nyata kehidupan di masyarakat dan pernyataan menurut saya, terkadang guru mengaitkan pembelajaran yang diberikan dengan budaya lingkungan setempat menjadi bentuk pernyataan pembahasan dan penjelasan yang guru berikan di sekolah dikaitkan dengan sosial budaya sesuai kondisi nyata kehidupan di masyarakat, serta menambahkan pernyataanpernyataan terkait pendekatan wali asrama, antara lain pernyataan wali asrama membantu mendorong kreativitas siswa untuk menentukan kegiatan pembentukan caracter building dan life skill yang ingin kami lakukan. Dimensi aktivitas belajar dan mengajar berjumlah 10 pernyataan, komunikasi dan partisipasi orang tua dengan pesantren berjumlah 10 pernyataan, interaksi guru dan wali asrama kepada siswa berjumlah 16 pernyataan dengan memodifikasi pernyataanpernyataan terkait interaksi wali asrama kepada siswa diantaranya pernyataan guru/ wali asrama menerima dengan tangan terbuka setiap permasalahan yang dikemukakan saya atau orang tua saya dan guru/ wali asrama pernah melaporkan permasalahan yang saya hadapi kepada orang tua saya. Adapun dimensi peraturan dan sanksi yang berlaku di pesantren berjumlah 10 pernyataan. Nilai cronbach's alpha variabel lingkungan non fisik pesantren adalah 0,891. Skor jawaban tiaptiap pernyataan yaitu 4 (sangat sesuai), 3 (sesuai), 2 (tidak sesuai), dan 1 (sangat tidak sesuai) untuk pernyataan positif maupun negatif.

Instrumen kecerdasan emosi menggunakan instrumen penelitian Rachmawati (2015) yang mengacu pada konsep Goleman (1995) dengan fokus pada 3 jenis emosi negatif yaitu emosi sedih, marah, dan takut yakni terdiri dari 9 pernyataan mengenai kesadaran akan emosi diri, 6 pernyataan mengenai kemampuan dalam mengelola emosi diri, 6 pernyataan mengenai motivasi dalam memperkuat emosi, 4 pernyataan mengenai kemampuan dalam berempati dan 5 pernyataan mengenai keterampilan dalam membina hubungan sosial, sehingga total 30 pernyataan. Nilai cronbach's alpha variabel kecerdasan emsoional adalah 0,819. Skor jawaban tiaptiap pernyataan yaitu 4 (selalu), 3 (sering), 2 (jarang), dan 1 (hampir tidak pernah) untuk pernyataan positif maupun negatif.

Penyesuaian remaja diukur dengan menggunakan instrumen Santrock dan Warshak (1979) yang terdiri dari empat dimensi penyesuaian yaitu hubungan pertemanan, kebiasaan, kesehatan emosional, dan penarikan diri. Pernyataan mengenai hubungan pertemanan berjumlah 12 pernyataan, kebiasaan berjumlah 9 pernyataan, kesehatan emosional berjumlah 6 pernyataan, dan penarikan diri berjumlah 3 pernyataan sehingga total 30 butir pernyataan. Nilai cronbach's alpha variabel penyesuaian diri adalah 0,787. Skor jawaban tiap-tiap 
pernyataan yaitu 5 (selalu), 4 (biasa), 3 (kadang-kadang), 2 (tidak biasa), dan 1 (hampir tidak pernah) untuk pernyataan positif maupun negatif. Hasil skoring data dijumlahkan pada masing-masing subvariabel sehingga diperoleh skor total, kemudian indeks dikategorikan dengan cut off yang digunakan pada masing-masing variabel adalah 1) kategori kurang : $0,00-60,00 ; 2)$ cukup baik : $60,01-80,00 ; 3)$ baik: 80,01-100,00.

Analisis data yang digunakan untuk mengidentifikasi karakteristik remaja dan karakteristik keluarga digunakan analisis statistik deskriptif seperti jumah, persentase, nilai rataan, standar deviasi, nilai minimum, dan nilai maksimum. Analisis deskriptif untuk mengidentifikasi karakteristik lingkungan non fisik pesantren, kecerdasan emosional dan penyesuaian remaja. Uji regresi linear berganda untuk menganalisis adanya pengaruh karakteristik remaja, karakteristik anak, lingkungan non fisik pesantren, dan kecerdasan emosi terhadap penyesuaian remaja. Sebelum dilakukan uji regresi linear berganda tersebut terlebih dahulu dilakukan uji asumsi klasik, yaitu uji normalitas, uji multikolinearitas, dan uji heteroskedastisitas.

\section{HAS SIL}

\section{Karakteristik Remaja dan Keluarga}

Hasil penelitian menunjukkan usia seluruh remaja berada pada kategori remaja awal (1215 tahun). Rata-rata usia remaja laki-laki adalah 13,68 tahun dan rata-rata usia remaja perempuan adalah 13,54 tahun. Usia minimum remaja adalah 12 tahun dan usia maksimum adalah 13 tahun. Jumlah remaja laki-laki dan remaja perempuan sama banyak yaitu masingmasing 50 orang. Berdasarkan pada urutan kelahirannya, hampir dari setengah remaja $(44,0 \%)$ tergolong kategori anak tengah.
Karakteristik keluarga penelitian ini menunjukkan hampir seluruh ayah dan lebih dari setengah ibu berkategori dewasa madya (41-65 tahun). Rata-rata usia ayah berusia 45.75 tahun dan rata-rata usia ibu 42,78 tahun. Mayoritas ayah dan ibu berpendidikan lulus S1 (16 tahun) yaitu sebanyak 61 orang ayah dan 49 orang ibu. Tingkat pendidikan tertinggi yang dicapai ayah dan ibu adalah lulus S3 (22 tahun) yaitu 2,0 persen pada ayah dan 3,0 persen pada ibu. Rata-rata lama pendidikan ayah adalah 16,56 tahun dan rata-rata lama pendidikan ibu selama 15,43 tahun. Proporsi terbanyak berdasarkan pekerjaan menunjukkan 53,0 persen ayah bekerja sebagai pegawai swasta dan 32,0 persen ibu berstatus tidak bekerja. Selanjutnya, hasil analisis menemukan rata-rata pendapatan keluarga Rp17.250.000,00 per bulan, paling banyak ada pada kisaran Rp10.000.001,00Rp20.000.000,00 per bulan (43,0\%). Kemudian, lebih dari tiga per empat keluarga remaja $(81,0 \%)$ termasuk ke dalam kategori keluarga sedang.

\section{Lingkungan Non fisik Pesantren}

Hasil penelitian menunjukkan bahwa skor capaian kualitas terbaik lingkungan non fisik pesantren tiap dimensi pada remaja laki-laki dan perempuan ada pada dimensi peraturan dan sanksi yang berlaku di pesantren ditunjukkan oleh item pernyataan bahwa guru maupun wali asrama memberi sanksi jika ada salah satu siswa mengganggu ketertiban baik di sekolah maupun di asrama dengan capaian jawaban setuju sebanyak 75,0 persen dengan rataan indeks dimensi peraturan dan sanksi yang berlaku di pesantren sebesar 70,37 dan standar deviasi 10,30. Hal ini menunjukkan bahwa siswa sudah memahami dan mampu memaknai manfaat kebaikan sejumlah peraturan dan sanksi yang berlaku di pesantren.

Tabel 1 Nilai minimum, maksimum, rataan, dan standar deviasi indeks lingkungan non fisik pesantren

\begin{tabular}{|c|c|c|c|c|c|c|c|}
\hline \multirow{2}{*}{ Variabel } & \multicolumn{3}{|c|}{ Laki-laki } & \multicolumn{3}{|c|}{ Perempuan } & \multirow{2}{*}{$\begin{array}{r}\text { Uji beda } \\
\text { (p-value) }\end{array}$} \\
\hline & Min & $\operatorname{Max}$ & Rataan \pm SD & Min & $\operatorname{Max}$ & Rataan \pm SD & \\
\hline $\begin{array}{l}\text { Lingkungan non fisik } \\
\text { pesantren }\end{array}$ & 43,00 & 88,00 & $67,01 \pm 7,69$ & 51,00 & 82,00 & $67,75 \pm 7,05$ & 0,668 \\
\hline $\begin{array}{l}\text { Metode, pendekatan guru } \\
\text { dan wali asrama, dan } \\
\text { kompetensi siswa }\end{array}$ & 39,00 & 85,00 & $68,42 \pm 9,22$ & 55,00 & 89,00 & $67,67 \pm 7,69$ & 0,636 \\
\hline $\begin{array}{l}\text { Aktivitas belajar dan } \\
\text { mengajar }\end{array}$ & 47,00 & 100,00 & $67,20 \pm 10,24$ & 40,00 & 87,00 & $66,73 \pm 10,81$ & 0,849 \\
\hline $\begin{array}{l}\text { Komunikasi dan partisipasi } \\
\text { orang tua dengan } \\
\text { pesantren }\end{array}$ & 33,00 & 97,00 & $63,00 \pm 12,90$ & 37,00 & 90,00 & $66,85 \pm 11,06$ & 0,123 \\
\hline $\begin{array}{l}\text { Interaksi guru dan wali } \\
\text { asrama kepada siswa }\end{array}$ & 33,00 & 83,00 & $65,37 \pm 9,43$ & 40,00 & 90,00 & $67,08 \pm 8,45$ & 0,373 \\
\hline $\begin{array}{l}\text { Peraturan dan sanksi yang } \\
\text { berlaku }\end{array}$ & 50,00 & 93,00 & $70,40 \pm 9,82$ & 50,00 & 100,00 & $71,07 \pm 10,78$ & 0,751 \\
\hline
\end{tabular}


Tabel 2 Nilai minimum, maksimun, rataan, dan standar deviasi indeks kecerdasan emosional dan dimensinya

\begin{tabular}{lccccccc}
\hline \multirow{2}{*}{ Variabel } & \multicolumn{4}{c}{ Laki-laki } & \multicolumn{2}{c}{ Perempuan } & Uji beda \\
\cline { 2 - 7 } & Min & Max & Rataan \pm SD & Min & Max & Rataan \pm SD & (palue) \\
\hline Kecerdasan emosional & 56,00 & 94,00 & $74,73 \pm 7,74$ & 58,00 & 94,00 & $76,35 \pm 9,69$ & 0,377 \\
$\quad$ Kesadaran diri & 51,00 & 96,00 & $80,22 \pm 10,22$ & 55,00 & 100,00 & $80,15 \pm 11,07$ & 0,978 \\
Pengaturan diri & 50,00 & 100,00 & $72,77 \pm 10,66$ & 50,00 & 100,00 & $73,22 \pm 13,36$ & 0,842 \\
Motivasi & 33,00 & 94,00 & $69,44 \pm 13,67$ & 44,00 & 100,00 & $73,33 \pm 14,15$ & 0,168 \\
Empati & 41,00 & 91,00 & $69,83 \pm 12,01$ & 41,00 & 100,00 & $74,17 \pm 16,08$ & 0,135 \\
Keterampilan sosial & 53,00 & 93,00 & $77,47 \pm 9,42$ & 53,00 & 100,00 & $78,67 \pm 11,27$ & 0,545 \\
\hline
\end{tabular}

Dimensi komunikasi dan partisipasi orang tua dengan pesantren pada remaja laki-laki dan dimensi aktivitas belajar dan mengajar pada perempuan merupakan dimensi yang memiliki nilai lebih rendah dibanding dimensi lainnya. Rataan indeks lingkungan non fisik pesantren pada remaja laki-laki yaitu 67,01 dan pada remaja perempuan yaitu 67,75 dan dapat dikategorikan kategori cukup baik. Hasil uji beda menunjukkan bahwa tidak ada perbedaan yang nyata antara preferensi remaja laki-laki dan perempuan yang tinggal di pondok pesantren terhadap lingkungan non fisik pesantren.

\section{Penyesuaian Remaja}

Hasil penelitian menurut rata-rata indeks tiap dimensi penyesuaian menunjukkan skor capaian pada setiap dimensi mencapai ratarata lebih dari 70,00. Rataan indeks capaian terbaik remaja laki-laki yaitu pada dimensi hubungan pertemanan ditunjukkan oleh item pernyataan teman-teman saya banyak mengenal saya dengan baik dengan capaian jawaban terbiasa sebanyak 57,0 persen dengan rataan indeks dimensi hubungan pertemanan sebesar 77,87 dan standar deviasi 8,42. Sementara itu, rataan indeks capaian terbaik remaja perempuan yaitu kebiasaan ditunjukkan oleh item pernyataan bahwa remaja perempuan jika merasa kesulitan dalam mengerjakan sesuatu, berupaya hingga bisa menyelesaikannya dengan baik dengan capaian jawaban selalu sebanyak 44,0 persen dan jawaban biasa sebanyak 42,0 persen dengan rataan indeks dimensi kebiasaan sebesar 78,27 dan standar deviasi 10,42 . Selanjutnya, temuan penelitian pada dimensi penarikan diri baik pada remaja laki-laki maupun remaja perempuan merupakan dimensi yang memiliki nilai paling rendah dibanding dimensi lainnya dengan rataan indeks sebesar 23,50 pada remaja lakilaki dan rataan indeks sebesar 19,83 pada remaja perempuan, sehingga dapat dikatakan bahwa contoh memiliki perilaku dan sikap penarikan diri yang sangat rendah. Adapun nilai rata-rata indeks penyesuaian remaja secara total adalah 76,95 dan standar deviasi 8,76. Hasil uji beda dari tiap dimensi penyesuain menunjukkan bahwa hanya pada dimensi kesehatan emosional terdapat perbedaan yang signifikan antara remaja lakilaki dan perempuan, yaitu kesehatan emosional laki-laki cenderung lebih baik dibandingkan perempuan. Namun jika dilihat dari keseluruhan variabel penyesuaian tidak ada perbedaan yang nyata antara remaja lakilaki dan perempuan.

\section{Pengaruh Karakteristik Keluarga, Lingkungan Non fisik Pesantren, dan Kecerdasan Emosional terhadap Penyesuaian Remaja}

Pengujian awal pada penelitian yang melihat kelayakan model regresi berdasarkan pada asumsi klasik regresi menunjukkan bahwa beberapa asumsi telah terpenuhi. Hal ini menunjukkan bahwa model regresi dapat digunakan untuk menguji pengaruh karakteristik remaja, karakteristik keluarga, lingkungan non fisik pesantren, dan kecerdasan emosional terhadap penyesuaian remaja.

Tabel 3 Nilai minimum, maksimum, rataan, dan standar deviasi indeks penyesuaian remaja

\begin{tabular}{|c|c|c|c|c|c|c|c|}
\hline \multirow{2}{*}{ Variabel } & \multicolumn{3}{|c|}{ Laki-laki } & \multicolumn{3}{|c|}{ Perempuan } & \multirow{2}{*}{$\begin{array}{l}\text { Uji beda } \\
\text { (p-value) }\end{array}$} \\
\hline & Min & $\operatorname{Max}$ & Rataan \pm SD & Min & $\operatorname{Max}$ & Rataan \pm SD & \\
\hline Penyesuaian & 63,00 & 96,00 & $76,83 \pm 7,51$ & 65,00 & 95,00 & $77,07 \pm 8,62$ & 0,781 \\
\hline $\begin{array}{l}\text { Hubungan } \\
\text { pertemanan }\end{array}$ & 56,00 & 94,00 & $77,87 \pm 8,42$ & 60,00 & 96,00 & $77,83 \pm 10,12$ & 0,949 \\
\hline Kebiasaan & 53,00 & 97,00 & $74,95 \pm 9,43$ & 61,00 & 100,00 & $78,27 \pm 10,42$ & 0,091 \\
\hline Kesehatan emosional & 58,00 & 100,00 & $77,75 \pm 9,47$ & 50,00 & 100,00 & $73,17 \pm 11,48$ & $0,028^{*}$ \\
\hline Penarikan diri & 0,00 & 58,00 & $23,50 \pm 13,54$ & 0,00 & 58,00 & $19,83 \pm 12,70$ & 0,166 \\
\hline
\end{tabular}


Jur. IIm. Kel. \& Kons.

Tabel 4 Koefisien regresi karakteristik remaja, karakteristik keluarga, lingkungan non fisik pesantren dan kecerdasan emosional terhadap penyesuaian remaja

\begin{tabular}{|c|c|c|c|}
\hline Variabel & $\begin{array}{c}\text { B } \\
\text { (Tidak Terstandardisasi) }\end{array}$ & $\begin{array}{c}\beta \\
\text { (Terstandardisasi) }\end{array}$ & Sign. \\
\hline Konstanta & 68,383 & & 0,000 \\
\hline Jenis kelamin remaja ${ }^{a)}$ & $-0,985$ & $-0,062$ & 0,274 \\
\hline Usia remaja (tahun) & $-0,843$ & $-0,052$ & 0,374 \\
\hline Usia ayah (tahun) & $-0,238$ & $-0,118$ & 0,088 \\
\hline Usia ibu (tahun) & 0,168 & 0,093 & 0,190 \\
\hline Lama pendidikan ayah (tahun) & $-0,397$ & $-0,069$ & 0,256 \\
\hline Lama pendidikan ibu (tahun) & $-0,043$ & $-0,011$ & 0,852 \\
\hline Pendapatan keluarga (rupiah/bulan) & $3,969 \mathrm{E}^{-1}$ & 0,517 & $0,000^{* *}$ \\
\hline Besar keluarga (orang) & $-1,304$ & $-0,166$ & $0,013^{*}$ \\
\hline Lingkungan non fisik pesantren (indeks) & 0,223 & 0,215 & $0,039^{*}$ \\
\hline Kecerdasan emosional (indeks) & 0,253 & 0,234 & $0,027^{*}$ \\
\hline $\mathrm{F}$ & \multicolumn{3}{|c|}{25,365} \\
\hline Sig. & \multicolumn{3}{|c|}{0,000} \\
\hline $\mathrm{R}^{2}$ & \multicolumn{3}{|c|}{0,740} \\
\hline Adjusted R Square & \multicolumn{3}{|c|}{0,711} \\
\hline
\end{tabular}

Keterangan: ${ }^{a} 1=$ laki-laki, $0=$ perempuan; ${ }^{*}$ signifikan pada $p<0.05,{ }^{* *}$ signifikan pada $p<0,01$

Hasil uji regresi linier berganda memperlihatkan bahwa besar keluarga berpengaruh negatif signifikan terhadap penyesuaian remaja $(B=-1,304)$ yang berarti setiap penurunan satu orang besar keluarga akan meningkatkan penyesuaian sebesar 1,304 poin. Sementara itu, pengaruh pendapatan keluarga $\left(B=3,969 \mathrm{E}^{-7}\right)$, lingkungan non fisik pesantren $(B=0,223)$, dan kecerdasan emosional $(B=0,253)$ bersifat positif yang berarti bahwa setiap peningkatan satu rupiah pendapatan keluarga berdampak pada semakin tingginya kualitas penyesuaian remaja sebesar 0,0000003969 poin. Setiap peningkatan satu satuan indeks lingkungan non fisik pesantren akan meningkatkan kemampuan penyesuaian remaja sebesar 0,223 poin dan setiap peningkatan satu satuan indeks kecerdasan emosi maka meningkatkan penyesuaian remaja sebesar 0,253 poin. Nilai Adjusted $R$-square dari model regresi sebesar 0,711 . Artinya, 71,1 persen varian penyesuaian remaja dapat dijelaskan oleh perubahan dalam variabel-variabel yang ada pada model regresi. Sisanya sebesar 28,9 persen penyesuaian diri remaja dipengaruhi oleh variabel lain yang tidak diuji dalam penelitian ini.

\section{PEMBAHASAN}

Periode kehidupan remaja merupakan tahapan penting dalam siklus kehidupan setiap individu dan sebagai periode yang diharapkan siap untuk menghadapi masa depannya. Pada masa transisi ini remaja tidak mau lagi diperlakukan oleh lingkungan keluarga dan masyarakat sebagai anak-anak (Maslihah, 2011). Monks, Knoers, dan Haditono (1992) mengelompokkan usia remaja kedalam tiga kelompok yakni remaja awal (12-15 tahun), remaja menengah (15-18 tahun), remaja akhir (18-21 tahun). Hasil penelitian memperlihatkan bahwa keseluruhan remaja berada pada kategori remaja awal yakni lebih dari satu perdua jumlah remaja secara total berusia 14 tahun yang duduk di bangku kelas delapan. Teori bioekologis, Bronfenbrenner (1979) dalam Santrock (2011) mengungkapkan bahwa lingkungan sosial terdekat remaja adalah keluarga dan sekolah yang berperan besar dalam keberhasilan perkembangan remaja melalui interaksi langsung mikrosistem dengan remaja atau hasil interaksi antarkedua mikrosistem. Dodge et al. (1994) menemukan bahwa salah satu faktor yang penting pada kehidupan keluarga adalah keadaan sosial ekonomi, yang berpengaruh pada masalah perilaku anak nantinya dan berkorelasi pada konteks sosial anak dan stabilitas hubungan pertemanan di masa remaja.

Lingkungan sekolah memiliki peran dalam menentukan tinggi rendahnya tingkat penyesuaian pada remaja. Penelitian yang dilakukan oleh Angus, Prater, dan Busch (2009) menunjukan bahwa siswa mencapai nilai yang lebih tinggi dalam ujian dikarenakan lingkungan pembelajaran sekolah yang sehat. Lingkungan sekolah menurut Hernawati dan Rahmatika (2016) memiliki peran besar dalam dalam proses perkembangan perilaku sosial remaja karena interaksi remaja terhadap lingkungan sekolah terjadi berkali-kali, 
sehingga remaja dituntut untuk beradaptasi dengan lingkungannya. Pondok pesantren merupakan salah satu sekolah berasrama pendidikan agama (Islamic Boarding School) yang memberikan pendidikan nilai nilai moral (Setyaningrum et al., 2016). Persepsi lingkungan sekolah secara signifikan berhubungan dengan kesuksesan akademik siswa, pandangan positif siswa dari lingkungan sekolah mereka menjelaskan prestasi akademik yang mereka peroleh sehingga lingkungan sekolah menjadi target yang berharga untuk meningkatkan hasil akademik (Gietz \& Mclntosh, 2014). Hasil uji deskriptif menunjukkan bahwa mayoritas siswa mempersepsikan lingkungan non fisik pesantren berkategori cukup baik. Sama halnya jika dilihat dari tiap dimensi, lebih dari separuh jumlah remaja secara total menunjukkan pada seluruh dimensi juga berkategori cukup baik. Kondisi ini menunjukkan bahwa sebagian besar remaja mempersepsikan lingkungan non fisik pesantren sudah cukup mendukung. Wang dan Holcombe (2010) menemukan persepsi siswa terhadap lingkungan sekolah secara langsung dan tidak langsung memengaruhi pencapaian prestasi akademik, iklim sekolah yang tepat mendukung remaja untuk dapat mengalami peningkatan keterlibatan dalam belajar dan pencapaian prestasi.

Kecerdasan emosional adalah kemampuan individu dalam mengenali, memahami perasaan dirinya dan orang lain, mengendalikan perasaannya sendiri, menjalin hubungan serta memotivasi diri sendiri untuk menjadi lebih baik (Setyowati et al., 2010). Keberhasilan seorang individu tidak hanya ditentukan oleh IQ tinggi, tetapi terlihat pula dari kemampuan memantau dan mengendalikan perasaan sendiri dan orang lain, serta menggunakan perasaan-perasaan itu untuk memandu pikiran dan tindakan. Hasil penelitian menunjukkan proporsi terbesar siswa pada tingkat kecerdasan emosional bahwa teridentifikasi memiliki kecerdasan emosi berkategori cukup baik (72,0\%). Sementara itu, jika dibandingkan antara remaja laki-laki dan perempuan hasil menunjukkan bahwa rata-rata indeks remaja laki-laki lebih rendah dibandingkan remaja perempuan. Hasil penelitian yang sama ditemukan juga oleh Brackett et al. (2004) yang menunjukkan bahwa tingkat kemampuan kecerdasan emosional perempuan secara signifikan lebih tinggi dibandingkan laki-laki karena kriteria hidup laki-laki lebih prediktif daripada perempuan dan ketidakmampuan laki-laki untuk merasakan emosi dan menggunakan emosi untuk memfasilitasi pikiran lebih tinggi daripada perempuan. Das dan Tripathy (2015) bahwa perempuan cenderung memiliki kecerdasan emosi yang lebih baik dan laki-laki cenderung memiliki perilaku agresi yang lebih tinggi. Hasil penelitian Masum dan Khan (2014) menemukan bahwa kecerdasan emosi yang lebih tinggi merupakan prediksi bagi kepuasan hidup. Denham, Zinsser, dan Bailey (2011) yang menyatakan bahwa melakukan sosialisasi emosi merupakan salah satu cara untuk meningkatkan kecerdasan emosi anak, orang tua yang dapat memberikan tanggapan positif terhadap emosi yang ditunjukkan anak akan menghasilkan emosi dan kompetensi sosial yang positif. Kecerdasan emosi juga merupakan salah satu elemen penting untuk remaja dalam melakukan penyesuaian. Dotterer dan Lowe (2011) bahwa keterlibatan sekolah menjadi prediktor penting dalam pencapaian prestasi akademik.

Kemampuan penyesuaian akan menjadi salah satu bekal penting dalam membantu remaja berhubungan dengan masyarakat luas dan beradaptasi dengan tantangan yang dihadapi. Pada penelitian ini, penyesuaian remaja dilihat dari 4 dimensi menurut Santrock dan Warshak (1979) yakni persepsi dan perilaku remaja dalam menjalin hubungan pertemanan, kebiasaan, kesehatan emosional, dan penarikan diri terhadap lingkungannya. Hasil penelitian menyatakan bahwa besar keluarga mempengaruhi negatif signifikan terhadap penyesuaian remaja. Menurut Gunarsa dan Gunarsa (2000) menyatakan kepadatan dalam sebuah keluarga dan jumlah anggota yang semakin besar dapat menimbulkan ketegangan yang berakibat lebih buruk pada perilaku antar anggota keluarga itu sendiri. Sementara itu, penelitian Uyun dan Yuwono (2006) menunjukkan bahwa pendapatan keluarga memberi pengaruh positif signifikan terhadap penyesuaian remaja. Keluarga dengan pendapatan yang besar membuka kesempatan orang tua untuk melakukan upaya-upaya peningkatan kualitas keluarga yang diantaranya bagi perkembangan anak dalam kualitas penyesuaian terhadap lingkungan. Selanjutnya hasil penelitian Huan et al. (2012) menunjukkan bahwa dukungan sosial guru terhadap remaja berpengaruh terhadap penyesuaian diri mereka di sekolah, penelitian ini juga menemukan bahwa persepsi hubungan guru dan siswa yang positif memberikan pengaruh yang nyata terhadap prestasi akademik, keterlibatan siswa di sekolah, penyelesaian tugas, dan penghormatan kepada guru. 
Kecerdasan emosi merupakan elemen penting dalam penyesuaian remaja. Hasil tersebut mendukung penelitian Ladd et al. (2008) menunjukkan bahwa kecerdasan emosi remaja laki-laki dan perempuan memengaruhi perkembangan dan penyesuaian remaja, yang artinya semakin tinggi kecerdasan emosi maka semakin tinggi pula kemampuan penyesuaiannya. Menurut Rusyanti (2013) menyatakan bahwa sekolah dengan sistem asrama, para remaja mendapatkan pendidikan dengan kuantitas dan kualitas yang berada di atas rata-rata pendidikan dengan sistem konvensional. Ketika menjadi remaja yang tinggal di pesantren mempunyai kegiatan yang harus dilakukan mulai dari bangun tidur di waktu subuh hingga tidur kembali. Hal ini menjadikan salah satu faktor pada hasil penelitian ini yang juga menunjukkan bahwa lingkungan non fisik pesantren berpengaruh positif signifikan terhadap penyesuaian remaja. Menurut Franky dan Chamundeswary (2014) kesuksesan siswa dalam mencapai prestasi akademiknya bukan bergantung kepada bagaimana cara orang tersebut menyesuaikan diri dengan lingkungannya, melainkan bagaimana orang tersebut mengerti untuk mengembangkan dan menggunakan kemampuannya secara maksimal.

\section{SIMPULAN DAN SARAN}

Rata-rata usia remaja berkategori remaja awal dengan jumlah 50 remaja putra dan 50 remaja putri dan hampir separuh keseluruhan remaja berkategori sebagai anak tengah. Rata-rata usia ayah dan ibu berada pada tahap dewasa madya, dan tingkat pendidikan ayah dan ibu mayoritas berpendidikan lulus S1 (16 tahun). Rata-rata keseluruhan pendapatan keluarga yaitu Rp17.250.000,00 per bulan dengan perolehan terbanyak berada pada tingkatan selang pendapata berkisar dari Rp10.000.001,00 sampai Rp20.000.000,00 per bulan. Rata-rata indeks kecerdasan emosional dan penyesuaian remaja laki-laki lebih rendah dibandingkan remaja perempuan. Jika dilihat secara total, capaian kecerdasan emosional dan penyesuaian remaja teridentifikasi berkategori cukup baik. Lingkungan non fisik pesantren pun menurut sebagian besar remaja juga mencapai kualitas berkategori cukup baik. Hasil uji pengaruh menunjukkan usia ayah, urutan kelahiran, pendapatan keluarga, besar keluarga, lingkungan non fisik pesantren, dan kecerdasan emosional berpengaruh terhadap kemampuan penyesuaian pada remaja.

Hasil penelitian telah mengungkapkan bahwa faktor-faktor yang berpengaruh terhadap penyesuaian remaja adalah lingkungan non fisik pesantren dan kecerdasan emosional yang baik pada diri remaja, maka disarankan kepada orang tua untuk menyeimbangkan pengembangan kecerdasan emosional remaja sehingga penyesuaian pada remaja meningkat dan siap menghadapi masa depan yang berkaitan erat dengan lingkungan disekitarnya. Pesantren untuk dapat berkontribusi membangun kemampuan penyesuaian remaja melalui proses pembelajaran yang menyeluruh, penanaman pendisiplinan serta nilai-nilai moral yang baik, penyesuaian praktik pembelajaran dengan tahap perkembangan siswa, dan interaksi yang semakin baik antara wali asrama, guru, orang tua, dan santri. Penelitian selanjutnya diharapkan dapat menganalisis lebih dalam mengenai lingkungan non fisik pesantren, kecerdasan emosi serta perilaku penyesuaian remaja untuk dapat memperjelas hubungan lingkungan non fisik pesantren, kecerdasan emosi, dan kemampuan penyesuaian remaja maka perlu juga menambahkan dengan perbandingan antar pesantren tradisional dan pesantren modern dan pada rentang usia yang lebih beragam.

\section{DAFTAR PUSTAKA}

[BKKBN] Badan Kependudukan dan Keluarga Berencana Nasional. (2005). Badan kebijakan program keluarga berencana nasional. Jakarta.

[BPS, BKKBN, Menkes RI] Badan Pusat Statistik, Badan Kependudukan dan Keluarga Berencana Nasional, dan Kementerian Kesehatan Republik Indonesia. 2012. Survei demografi dan kesehatan Indonesia: kesehatan reproduksi remaja. Jakarta, ID: Direktorat Statistik Kependudukan dan Ketenagakerjaan BPS.

Angus, J., M., Prater, D., L., Busch, S. (2009). The effects of school culture and climate on student achievement. International Journal Leadership In Educaton, 12(1), 73-84.

Brackett, M., A., Mayer, J., D., Warner, R., M. (2004). Emotional intelligence and its relation to everyday behaviour. Journal Personality and Individual Differences, 36(6), 1387-1402.

Bronfenbrenner, U. (1979). The ecology of human development. Cambridge, USA: Harvard University Press. 
Bronfenbrenner, U. (1985). Ecology of the family. Cambridge, USA: Harvard University Press.

Das, P., P., P., \& Tripathy, S. (2015). Role of emotion intelligence on aggression: a comparison between adolescent boys and girls. Journal of Psycology and Bahavioral Sciences, 4(1), 29-35.

Denham, S., A., Zinsser, K., \& Bailey, C., S. (2011). Emotional intelligence in the first five years of life. Encyclopedia on early childhood development. Virginia, USA: George Manson University.

Dhofier, Z. (1985). Tradisi pesantren: studi tentang pandangan hidup kyai. Jakarta, ID: LP3ES

Dodge, K., A., Pettit, G., S., \& Bates, J., E. (1994). Socialization Mediators of The Relation between Socioeconomic Status dan Child Conduct Problems. Journal Child Development, 65(2), 649-665.

Dotterer, A., M., \& Lowe, K. (2011). Classroom context, school engagement, and academic achievement in early adolescence. Springer, J Youth Adolescence, 40, 1649-1660.

Dwiperdanasari, Y. (2010). Perbedaan tingkat kecerdasan emosional ditinjau dari lingkungan tempat tinggal remaja (antara remaja yang tinggal di pondok pesantren dan remaja yang tidak tinggal di pondok pesantren). Jurnal Psikologi, 14(1), 8-19.

Efendi, A., M. (2013). Hubungan antara konsep diri dan pola asuh orang tua dengan konformitas santri. Jurnal Penelitian Humaniora, 14(1), 1-8.

Franky, D., \& Chamundeswari, S. (2014). Psycho-social correlates of academic achievement of students. International Journal of Current Research and Academic Review, 2(2), 148-158.

Gietz, C., \& Mclntosh, K. (2014). Relations between student perceptions of their school environment and academic achievement. Canadian Journal of School Psychology, 29(3), 161-176.

Goleman, D. (1999). Working with emotional intelligence: kecerdasan emosi untuk mencapai puncak prestasi (penerjemah: Alex Tri Kantjo Widodo). Jakarta, ID: Gramedia Pustaka Utama.

Goleman, D. (2005). Kecerdasan emosional. (penerjemah: Hermaya T.). Jakarta, ID: Gramedia Pustaka Utama.
Gottman, J., \& DeClaire, J. (2001). Kiat-kiat membersarkan anak yang memiliki kecerdasan emosional. Jakarta, ID: Gramedia Pustaka Utama.

Handono, O., T., \& Bashori, K. (2013). Hubungan antara penyesuaian diri dan dukungan sosial terhadap stres lingkungan pada santri baru. Jurnal Fakultas Psikologi, 1(2), 79-89.

Hernawati, N., \& Rahmatika, M. (2016). The influence of school environment, social intelligence, and self- esteem toward academic achievement of student in rural area. Journal of Child Development Studies, 1(1), 28-39.

Huan, V., S., Quek, G., C., L., Yeo, L., S., Ang, R., P., \& Chong, W., H. (2012). How teacher-student relationship influenced student attitude towards teachers and school. The Asia-Pacific Education Researcher, 21(1), 151-159.

Hurlock, E. B. (2002). Psikologi perkembangan. $5^{\text {th }}$ edition. Jakarta, ID: Erlangga.

Kidger, J., Araya, R., Donovan, J., \&Gunnel, D. (2011). The effect of the school environment on the emotional health of adolescents: a systematic review. Journal Pediatrics, 129(5), 1-25.

Kurniati, Y., \& Susandari. (2014). Hubungan antara character strength dengan penyesuaian diri pada santri putri kelas intensif Ponpes Al Basyariyah Kabupaten Bandung. Di dalam: Psikologi, Gelombang 2, Tahun Akademik 2014-2015. Prosiding Psikologi. Bandun, ID: Unisba. hlm. 588596

Ladd, G., W., Becky, J., \& Coleman, C. (2008). Friendship quality as a predictor of young children's early school adjustment. Journal Child Development, 67(3), 11031118.

Maslihah, S. (2011). Studi tentang hubungan dukungan sosial, penyesuaian sosial di lingkungan sekolah dan prestasi akademik siswa SMPIT Assyfa Boarding School Subang Jawa Barat. Jurnal Psikologi, 10(2),103-114.

Masumi, R., \& Khan, I. (2014). Examining the relationship between emotional intelligence and aggression among undergraduate students of Karachi. Journal of Educational Research International, 3(3), 36-41. 
Monks, F., J., Knoers, A. M. P., \& Haditono, S. R. (1992). Psikologi perkembangan dalam berbagai bagiannya. Yogyakarta, ID: Gajah Mada University Pers.

Morrison, T. (2007). Emotional intelligence, emotion and social work: context, characteristics, complications and contribution. British Journal of Social Work, 37, 245-263.

Mu'tadin, Z. (2002). Penyesuaian diri remaja. Diambil dari: http://www.e-psikologi.com [Diunduh pada 16 Februari 2016].

Nurhayati, E., \& Yasin, B. N. (2009). Pengaruh lingkungan sosial dan nonsosial pondok pesantren terhadap prestasi belajar matematika siswa kelas VIII MTS Husnul Khotimah Pondok Pesantren Husnul Khotimah Manis Kidul Jalaksana Kuningan. Jurnal Edukasi Matematika, 1(1), 65-74.

Rachmawati, M. (2015). Pengaruh sosialisasi emosi dan kecerdasan emosional terhadap perilaku agresi anak usia sekolah pada keluarga pedesaan (Skripsi). Institut Pertanian Bogor, Bogor, Indonesia.

Rusyanti, H. (2013). Boarding school: pengertian boarding school. Diambil dari:

http://www.kajianteori.com/2013/03/boar ding-school-pengertian-boardingschool.html. [Diunduh pada 29 desember 2015].

Santrock, J. W. (2007). Remaja. Buku 2. (Penerjemah: Benedictine Widyasinta). Jakarta, ID: Erlangga. Terjemahan dari: Adolescence. Ed ke-11.

Santrock, J. W., \& Warshak, R. A. (1979). Father sustody and social development in boys and girls. Journal of Social Issues, 35, 112-125.

Sayu, J., A., Ibrahim, M., Y., \& Budjang, G. (2007). Adaptasi sosial siswa kelas $x$ pada boarding school SMA Taruna Bumi Khatulistiwa. Jurnal Sosiologi, 5(1), 8496.

Schneiders. (1964). Personal adjustment and mental health. New York, USA: Holt, Reinhart \& Winston Inc.

Setyanigrum, Y., I., Amin, M., Hastuti, A., S., \& Suarsini, E. (2016). Life cycle sarcoptes scabiei and pathogenicity mite in Boarding School Malang, Indonesian. International Journal of ChemTech Research, 9(3), 384-389.
Setyowati, A., Hartati, S., \& Sawitri, R. (2010). Hubungan antara kecerdasan emosional dengan resiliensi dada siswa penghuni rumah damai. Jurnal Psikologi Undip, 7(1), 57-77.

Utami, A N. (2014). Pengaruh gaya pengasuhan dan lingkungan non fisik sekolah terhadap karakter remaja (Skripsi). Institut Pertanian Bogor, Bogor, Indonesia.

Uyun, E., S., Z., \& Yuwono, S. (2006). Hubungan antara penyesuaian sosial dan kemampuan menyelesaikan masalah dengan kecenderungan perilaku delinkuen pada remaja. Jurnal Psikologi Universitas Diponegoro, 3(1), 29-35.

Wang, M., T., \& Holcombe, R. (2010). Adolescents' perceptions of school environment, engagement, and academic achievement in middle school. American Educational Research Journal, 47(3), 633-662.

Wang, M. (2009). School climate support for behavioral and psychological adjustment: testing the mediating effect of social competence. Journal School Psychology Quarterly, 24(4), 240-251. 